IJIET, e-ISSN 2548-8430, p-ISSN 2548-8422, Vol. 2, No. 2, July 2018

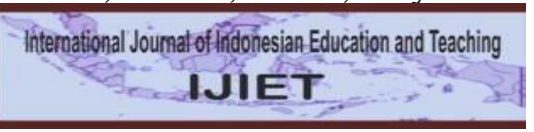

International Journal of Indonesian Education and Teaching http://e-journal.usd.ac.id/index.php/IJIET

Sanata Dharma University, Yogyakarta, Indonesia

\title{
THE APPLICATION OF SOCIAL SKILL TRAINING AS INTERVENTION TO IMPROVE SOCIAL SKILL FOR A SMALL NUMBER OF FRESHMEN STUDENTS
}

\author{
Laurentius Sandi Witarso and Dhamayanti B. Utoyo \\ Universitas Indonesia \\ 1sandiwitarso@gmail.com and utoyo@gmail.com \\ https://doi.org/10.24071/ijiet.v2i2.1183 \\ received 14 April 2018; revised 1 June 2018; \\ accepted 25 June 2018
}

\begin{abstract}
Being freshmen is a challenge for college students. They must encounter a lot of demands in their college especially their social skills. Prior research showed that students of Universitas Indonesia reported their social-psychological relations problem in their social environment. Freshmen must have adequate social skills in order to encounter demands in social relation. This study aimed to increase social skills for Universitas Indonesia's freshmen through the application of Social Skill Training (SST). A pre-test, post-test design and one month follow up test were administered. Subjects of this study were seven Universitas Indonesia's students (freshmen) with age range from $17-18$ years old, attended three sessions with two hours per session. Participants reported that their social skills increased, indicated by improvement in Social Skills Inventory (SSI), and also by qualitative evaluation. Group dynamics and experiential learning allowed them to learn from the experiences of other participants. Therefore, the application of Social Skills Training effectively increased the social skills for Universitas Indonesia's freshmen. Further research is needed to examine this intervention using a larger sample, control groups and in-depth interview for qualitative evaluation.
\end{abstract}

Keywords: college student, freshmen, social skill, training

\section{Introduction}

People who continue their level education to the college definitely encounter some changes in their lives. At this stage, they encounter the changes related to school system, relationship with peer from different areas and cultures, and high need of achievement (Santrock, 2012). They will leave home, friends, familiar environment, and must adapt to the new environment (David \& Nită, 2014).

The changes evoke the challenge that must be encountered by the freshmen when they enter the college. Some of the usual problems that arise include anxiety, depression, loneliness, and feel alienated (Kneipp, Kelly \& Cyphers 2009). A problem of social relations is one of the four main problems in Universitas Indonesia's student (Utama, 2010). Prior research showed a total of 9,1\% of Universitas Indonesia students have severe psychological problem when 
dealing with their social environment such as feel ashamed, uncomfortable with others and have no friends on campus (Utama, 2010). The statements below are the description that encountered by freshmen student when they enter the university/college life.

"I want to be more open. I know that I'm introvert and I'm not always open to others, except with people I've known for a long time. But because I know that Universitas Indonesia demand their students to be more active, so what else?" (ER, female, 17 years old, Faculty of Humanities - Universitas Indonesia)

"I want to eliminate my social anxiety that I often encounter when dealing with $n w$ peoples, especially in the university environment" (MRU, male, 18 years old, ER, female, 17 years old, Faculty of Humanities - Universitas Indonesia)

Sekararum (2012) did an interview with the students related to the demand they encountered being the freshmen students. The interview results showed that to be successful in the university, not only being smart academically but also musthave skills to build good relationship with others which is needed when they workin group in class, getting information about academic context, or deal with lecturers or campus staffs. Freshmen students are in emerging adulthood stage which have task to build relationship with others. Social skills at emerging adulthood stage play an important role considering their need for social integration and the search for self-assertion and independence (Hohendorff, Couto, Prati, 2016). People must have good social skill to fulfil the demands of social environment (Segrin, 2001). It can be concluded that social skill is the communication ability that is very important for a university student.

Riggio and Reichard (2008) define social skill as an ability to express the self when interact with others, able to read and understand any social situation, having knowledge about social roles, norms and rules. A person with low social skill will encounter difficulties when interact with others, limit their chance to build their relationship. They also probably have to experience any psychopathology like depression, social phobia, the onset of schizophrenia and also psychosocial problems such as loneliness, anxiety and depression (Segrin, 2001). On the contrary, a person with good social skill, will deal with any positive things psychologically like social support, success in social relationship, create the positive skill like empathy and increase the self-esteem (Sekararum, 2012).

There are some interventions that can be done to increase social skills; one of them is training. Social skill training is an intervention that makes individual gain a number of basic behaviors so that they get the desired impression from others and improves success in social situation (Spence, 2003). Researcher on this study will use the module arranged by Siregar (2012) who conducted Social Skill Training to increase social skill and decrease psychological distress of university students. This intervention is focused on experiential learning principle where participants can learn actively from the concrete experience and testing implications of concepts in new situation. Hypothesis in this study is social skill can be improved through social skill training. 


\section{Theory \\ Social Skill}

Social skill is an ability to express oneself in social interactions, the ability to read and understand different social situations, knowledge of social roles, norms, and scripts, interpersonal problem-solving skills, and social role-playing skills. Social skill consists of three basic skills: skill in expression, skill in recognizing and decoding messages from others, and skill in regulating and controlling communication behaviors (Riggio \& Reichard, 2008).

\section{Social Skill Training}

Social skills training involves intervention that enable person to acquire an adequate repertoire of basic behaviors that have a strong impact upon the impression made upon others and that increase the chance of successful outcomes from social situations (Spence, 2003)

\section{Experiential Learning}

Experiential learning is a learning approach which focused on students. Students are required to be actively involved, process and interpret their concrete experience and have a high intention to apply the learning process (Supratiknya, 2009). Experiential learning approach according Lewin (Kolb, 1984) consists of 4 cycles. First, people get a concrete experience directly. Second, observations and reflections, people reflect on their concrete experience gained. Third, formation of abstract concepts and generalizations, a process of assimilation and integration of the experiences. Fourth, testing implications of concepts in new situation, where people apply their learning result in daily life.

\section{Method}

This research used a single-case study design, pre-post intervention. Participant was evaluated before and after the intervention phase (pre-test and post-test) and upon 1.5 month follow up phase. The measurement of social skill used Social Skill Inventory (SSI). It consists of 90 items which include 6 dimensions; emotional expressivity, emotional sensitivity, emotional control, social expressivity, social sensitivity and social control (Riggio \& Carney, 2003). Participants of this intervention were freshmen students of Universitas Indonesia who have problem with their social skill which seen by their Social Skill Inventory score. This intervention was conducted at Faculty of Psychology, Universitas Indonesia.

The intervention used convenience sampling method to select the participants with consideration of their availability and willingness to respond (Graveter \& Forzano, 2015) Researcher conducted a screening process by administering a questionnaire (Social Skill Inventory and open questionnaire) which will be utilized as a pre-test data. The questionnaires are distributed on the internet using google form to Universitas Indonesia's freshmen student. Participants who filled the questionnaire were selected by researcher based on their Social Skill Inventoryscore below and the willingness to join the intervention. Researcher on this study will use the module arranged by Siregar (2012). 
Table 1. Content of Intervention Sessions

\begin{tabular}{|c|c|}
\hline Session & Aim \\
\hline I Share & $\begin{array}{l}\text { Participants realize the importance of understanding } \\
\text { and self-expressing effectively and understanding } \\
\text { how to develop it. }\end{array}$ \\
\hline I think & $\begin{array}{l}\text { Participants realize that negative thought is an } \\
\text { obstacle in presenting social skills and understand } \\
\text { how to cope it. }\end{array}$ \\
\hline I Feel & $\begin{array}{l}\text { Participants realize that negative emotion is an } \\
\text { obstacle in presenting social skills and understand } \\
\text { how to cope it. }\end{array}$ \\
\hline I Express & $\begin{array}{l}\text { Participants realize the importance of verbal and } \\
\text { nonverbal communication appropriately and } \\
\text { understand how to develop it. }\end{array}$ \\
\hline I Care & $\begin{array}{l}\text { Participants realize the importance of understanding } \\
\text { and empathy with others and understand how to } \\
\text { develop it. }\end{array}$ \\
\hline I Listen & $\begin{array}{l}\text { Participants realize the importance of active listening } \\
\text { as a positive communication behavior and understand } \\
\text { how to develop it. }\end{array}$ \\
\hline
\end{tabular}

\section{Findings and Discussion}

Data Analysis

Data were analyzed quantitatively using Friedman rank test (nonparametric statistic) to assess change Social Skill Inventory score between beforeafter the intervention and score between before intervention and follow up score. Besides, researcher used qualitative data by utilizing open questionnaire to obtained feedback from participants.

Table 2. Social Skill Score

\begin{tabular}{cccc}
\hline Participant & $\begin{array}{c}\text { Pre } \\
\text { Test }\end{array}$ & $\begin{array}{c}\text { Post } \\
\text { Test }\end{array}$ & $\begin{array}{c}\text { Follow } \\
\text { Up }\end{array}$ \\
\hline NCP & 231 & 262 & 265 \\
SL & 222 & 222 & 228 \\
AM & 216 & 228 & 231 \\
MRU & 233 & 247 & 257 \\
KR & 223 & 224 & 232 \\
ER & 210 & 213 & 238 \\
RAM & 240 & 240 & 242 \\
\hline Mean & 225.00 & 233.71 & 241.85
\end{tabular}

Table 3. Statistical Analysis

\begin{tabular}{cc}
\hline $\mathrm{N}$ & 7 \\
Chi-square & 13.231 \\
$\mathrm{df}$ & 2 \\
Asymp. Sig. & $.001 *$ \\
\hline$* \mathrm{p}<0.05$ &
\end{tabular}


A total seven participants took part in the study had a mean age 17,7 years old, consists of two males and five females. They completed pre-test, post-test, followup and feedback forms. According to statistical analysis, suggest that there was significant score of social skills between pre-test, post-test and follow up phase. This indicated by a Sig. level of 0.01. Comparing the mean, there was increase in social skills over time.

Table 4. Qualitative Evaluation

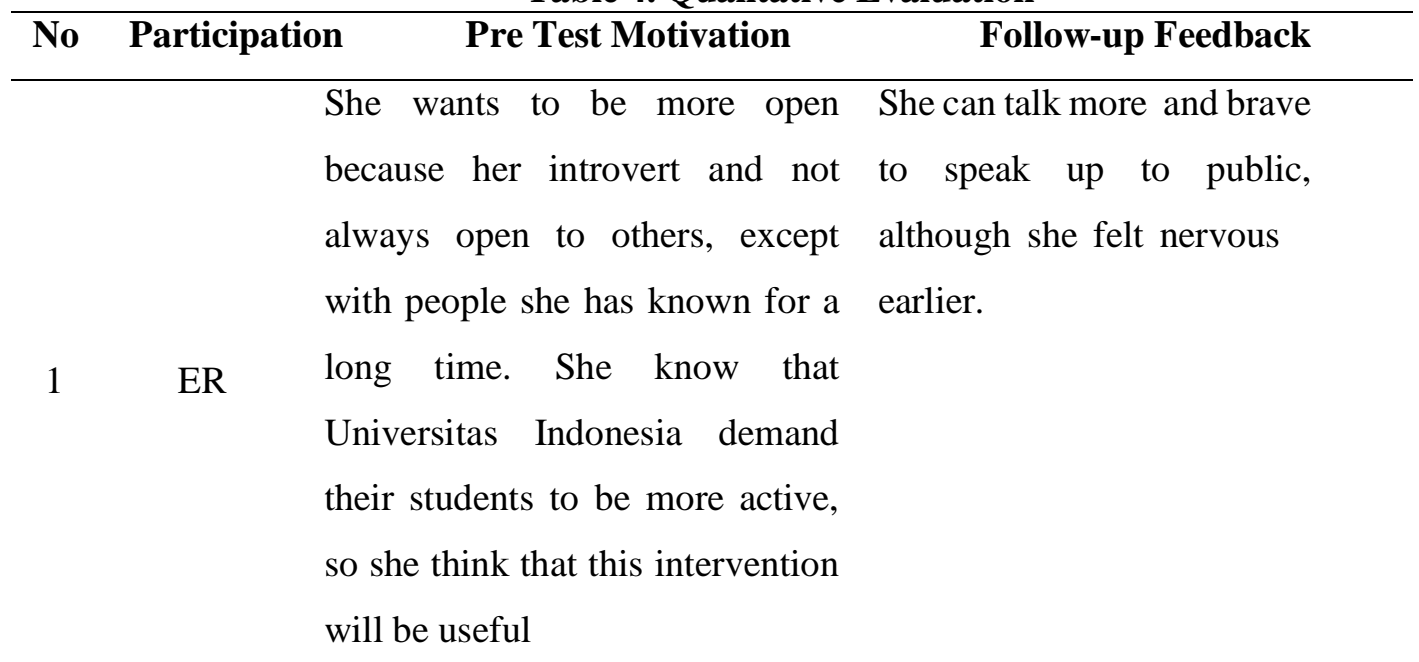

She wants to know how to build

a good social relation with the

$2 \quad \mathrm{KR}$

3 MRU

4 others student in Universitas

Indonesia

He wants to eliminate the social anxiety that he often experiences when facing new people, especially in campus environment

She wants to increase her social skill in order to get a lot of social relation.
She found that it's easier to speak in front of public, more appreciate the people who talk to her, braver to try something new, and braver to speak up her opinion.

$\mathrm{He}$ is braver to join committees that involve a lot of people, braver to acquainted with a lot of people, begin to talk better as taught in the training, and understand other's feeling when talk to them. $\mathrm{He}$ currently is still trying to apply the $\mathrm{ABCDE}$ concept in daily basis.

She is now having more friends, more understanding and could handle other people, more confident. 


\begin{tabular}{|c|c|c|c|}
\hline 5 & SL & $\begin{array}{l}\text { She feels annoyed by her } \\
\text { minimum social skill. }\end{array}$ & $\begin{array}{l}\text { She could understand herself more and } \\
\text { realize that the improvement of social } \\
\text { skill requires time and process. }\end{array}$ \\
\hline 6 & $\mathrm{NCP}$ & $\begin{array}{l}\text { She wants to increase his } \\
\text { confidence, eliminate his } \\
\text { 'anti-social' trait of her. }\end{array}$ & $\begin{array}{l}\text { She experiences more activities, having } \\
\text { fun with friends, less minding about } \\
\text { other people thinking about her. }\end{array}$ \\
\hline 7 & RAM & $\begin{array}{l}\text { He wants to make the social } \\
\text { skill as an assets in facing } \\
\text { university life. }\end{array}$ & $\begin{array}{l}\text { He could think more positively and he } \\
\text { feels that this training helps him } \\
\text { socialize in campus environment. }\end{array}$ \\
\hline
\end{tabular}

Based on the qualitative analysis results, found that all the participants get the positive improvement of social skill after joining this intervention. At first, they were interested to join this intervention because they mostly felt that their skills to socialize with other people are low. Some of them felt that they have traits that inhibit them from performing good social skill such as: behaving less openly to other people, feeling antisocial, and feeling having social anxiety when they are with other people. One month and a half after finishing this intervention, participants experience positive outcome in their social skill, such as: braver to speak in front of public, feeling more comfortable to build social relation, and more understanding of themselves and others.

The aim of this study is to analyzing the application of social skill training to increase college freshmen's social skill. The hypothesis was social skill of Universitas Indonesia's freshmen student can improve through social skill training. This research showed that, there was change of score between pre-test, post-test and follow-up measurement.

The main factor in this study is experiential learning as a principle in this training which is very effective to improve their social skill. Participants on this study are actively involved so they could gain their concrete experience, make a reflection and conclude their reflection according the concept (Lewin, as cited in Kolb, 1984; Supratiknya, 2009). Facilitator as a mediator helps participants to discuss and carry out their experiences related to social skills. This is also supported by the high commitment of participants during the training. Besides, participants could learn from the others experiences related to social skill.

The number of subjects only a few (seven participants) so that learning process can be created conducive and there were formed group dynamic. In this group, there were similar issues related every participants so that they become more open in expressing what has been felt so far.

\section{Conclusion}

This study proofs that the social skill training could improve social skill among the freshman students of Universitas Indonesia. This is based on thequantitative analysis result that shows increasing score of SSI during the pre-test, 
post-test, and follow up sessions. However, this result didn't show that this intervention is proven applicable to larger population due to the few amounts of participants that included (seven peoples in total).

Meanwhile based on the qualitative analysis results, found that all the participants experiencing plenty benefits after joining this training. The social skill training helps them to become more open to other people, more understand themselves and others, and more comfortable in interacting with other people.

For further research, we suggest this design to be done again for having to make sure the effectiveness of social skill training in freshman students. A few numbers of this study's participants makes us suggest further research to be done by including larger numbers of participants as well as including control group instead of single experimental group. This aims to ensure that the changes in participant's social skill are due to this training conducted by researchers. This study also not including assessment before initiating the intervention and probing further feedback after the intervention is done. This could be done by using in- depth interview before and after the intervention is done.

\section{References}

David, L. T., \& Nită, G. L. (2014). Adjustment to first year of college-relations among self-perception, trust, mastery and alienation. Procedia-Social and Behavioral Sciences, 127, 139-143.

Gravetter, F. J., \& Forzano, L. A. B. (2015). Research methods for the behavioral sciences. Belmont: Wadsworth.

Kneipp, L. B., Kelly, K. E., \& Cyphers, B. (2009). Feeling at peace with college: Religiosity, spiritual well-being, and college adjustment. Individual Differences Research, 7(3).

Kolb, D. A. (1984). Experiential learning: Experience as the source of learning and development. Englewood Cliffs, NJ: Prentice-Hall, Inc.

Riggio, R. E., \& Reichard, R. J. (2008). The emotional and social intelligences of effective leadership: An emotional and social skill approach. Journal of managerial psychology, 23(2), 169-185.

Santrock, John W. (2012). Life span development (14 ${ }^{\text {th }}$ ed.). New York: Mc GrawHill

Segrin, Chris. (2001). Social skills and negative life events: Testing the deficit stress generation hypothesis. Current Psychology, 20(1), 19-35.

Sekararum, A. (2012). Interpersonal psychotherapy (IPT) untuk meningkatkan keterampilan sosial mahasiswa universitas Indonesia yang mengalami distres psikologi (Tesis. Depok: Magister Fakultas Psikologi Universitas Indonesia).

Siregar, D.A.I.S. (2012). Pelatihan keterampilan sosial untuk mahasiswa universitas Indonesia dengan distres psikologis tinggi (Tesis. Depok:Magister Fakultas Psikologi Universitas Indonesia).

Spence, S.H. (2003). Social skills training with children and young people: Theory, evidence, and practice. Child and Adolescent Mental Health, 8(2), 84-96.

Supratiknya, A. (2008). Merancang program dan modul psikoedukasi. Yogyakarta: Universitas Sanata Dharma. 
IJIET Vol. 2, No. 2, July 2018

Utama, B. (2010). Kesehatan Mental dan Masalah-Masalah pada Mahasiswa S1 Universitas Indonesia (Skripsi. Depok: Sarjana Fakultas Psikologi Universitas Indonesia).

Von Hohendorff, J., Couto, M. C. P. D. P., \& Prati, L. E. (2013). Social skills in adolescence: Psychopathology and sociodemographic variables. Estudos de Psicologia (Campinas), 30(2), 151-160. 